\title{
sciendo
}

DOI 10.2478/sbe-2019-0037

SBE no. 14(2) 2019

\section{INVESTMENTS, ECONOMIC GROWTH AND EMPLOYMENT: VAR METHOD FOR ROMANIA}

\author{
VODĂ ALINA DANIELA \\ Lucian Blaga University of Sibiu, Romania \\ DUGULEANĂ LILIANA \\ Transilvania University, Brașov, Romania \\ DOBROTĂ GABRIELA \\ Constantin Brâncuși University, Târgu-Jiu, Romania
}

\begin{abstract}
:
Economic growth can be seen as an effect of both fiscal policies and different legislative norms applied at national and macroeconomic level. Investments are a determining factor in the evolution of socio-economic life, influencing also the employment rate. This paper aims to identify the influence of investments on economic growth and employment using the vector autoregressive model (VAR). Based on the quarterly data from Romania, between the first quarter of 2000 and the second quarter of 2018, the Granger causality test and the impulse - response function was applied to identify the effect of the investments on the sustainable development of the Romanian economy. The results revealed that investments in Romania influence the economic growth and, implicitly, the employment. In terms of impulse - response function, a negative relationship between investment and employment was identified, which may be due to the fact that the need for human resources is no longer a priority in some sectors of activity due to technology.
\end{abstract}

Key words: Investments, economic growth, employment

\section{Introduction}

Investments, irrespective of their type, can be defined as a mechanism to multiply cash or other benefits expected in the future. At the macroeconomic level, they are recognized as an important indicator of economic development characterization, having an impact both on gross domestic product and on employment. Due to the fiscal policies applied in Romania for the economic recovery during the financial crisis, which occurred in the last quarter of 2008, the business environment had a fluctuated evolution, many companies failing to reach the economic maturity required to remain on the market. Since 
the business environment is also a determinant factor in the development of socioeconomic life, both the employment and the gross domestic product of the country are in close correlation with it. Thus, investments, gross domestic product and employment experienced an upward trend until 2008, when the economic shock coming from the United States was to create a strong imbalance in the Romanian economy. This article is about the assessment of three indicators: gross domestic product (GDP), employment (EMP) and investments (GFCF), based on which the vector autoregressive model (VAR) will be analyzed using quarterly data, between 2000 the first quarter and 2018 the second quarter. The use of the VAR model will provide the opportunity to apply the Granger causality test and the impulse - response function to identify the discretionary effects of investments, gross domestic product and employment on economic development.

\section{Literature review}

In the specialty literature, there are many opinions about the economic growth and the impact of various macroeconomic indicators, especially of the investments on it. Mordecki et al. (2014) have conducted a comprehensive study to capture the impact of investment on Uruguay's economic growth, mentioning that "investment is a key to analyze an economy's growth, as its increase the economy productive capacity, either expanding the capital stock as incorporating new technology that makes the production process more efficient", identifying based on the vector error correction model (VECM), "positive relationship between GDP and the other two variables, where GDP precedes both urban workers and investment". "However, the relationship between employment and investment is not so clear and in some cases appears to be negative, which could be showing a phenomenon of saving labor investment, or investment in less labor intensive sectors" (Mordecki et al. 2014). Bond et al. (2010) states that "the share of investment in GDP has a large and significant effect, not only on the level of output per worker, but more importantly on its long-run growth rate", a result based on the analysis of the annual data collected for a large sample of countries using aggregated data for five-year periods and the use of estimated average effects from time series models for each country individually. Cheung et al. (2012) have a contradictory opinion on the impact of investment on economic growth. They argue that the effect of investment varies over time as well as by country and "the evidence does not support any one theory of why investment in high income countries is not associated with growth". Attanasio et al. (2000) identifies, based on the Granger causality test, that savings Granger - causes investment, and in analogy, growth Granger - causes investment, while there is no evidence of causation going from investment to economic growth. A similar result was supported on the basis of statistical data analysis by Blomstrom et al. (1993), noting that there is no evidence that investment is the key to economic growth. Yaylı and Değer (2012) analyzed the unidirectional causal relationship from foreign direct investments to employment for 27 developing countries in the period 1991 - 2008. A number of other authors like Mucuk et al. (2013), Jayaraman and Singh (2007), Jula and Jula (2017) and Maitah et al. (2014), studied the effect of investment on growth in both developed and emerging countries. 
Although the empirical results are contradictory, the analysis of the existing information for Romania for a period of 19 years was carried out in order to identify the existing situation at national level and to draw the most conclusive conclusions for explaining this phenomenon.

\section{The research methodology}

To achieve the result of this research we proceeded to estimate the unrestricted vector autoregressive model (VAR) by evaluating the impulse - response function. This function provides the possibility of estimating the response of certain variables to the shock produced by other variables analyzed in the model, namely, the effect of a shock (impulse or innovation) of the independent variable with one standard deviation on the dependent variable. The variables used to create the econometric model are: gross domestic product (GDP), employment (EMP) and investments (GFCF). They are recognized as endogenous variables because they determine the level of economic activity at national level, unlike the exogenous variables used by Keynes in his works, which characterize the behavior of economic entities.

The vector autoregressive model was created using quarterly data between first quarter of 2000 and the second quarter of 2018 (74 observations), taken from Eurostat. The time series were seasonally adjusted and to be expressed in real terms, in 2010 prices, both gross domestic product and investments were deflated using GDP deflator whose base year is 2010. Generally, variables are logged for a normal data distribution where some values are too high or too low for certain periods, leading to an easier interpretation of coefficients obtained from regression. Thus, the three variables were expressed in logarithms.

It is necessary to test the time series for stationarity before testing the model. The Augmented Dickey-Fuller test (ADF) and the Phillips-Perron test (PP) were applied and the results are detailed in Table 1. From an economic point of view, a data series is stationary if a shock is temporary, does not have a unit root, being integrated of the first order (1). The three variables used in the model are not stationary, and using the first order differences, they become stationary.

Table 1. The result of the Augmented Dickey - Fuller and Phillips-Perron tests for the initial variables and the first order differences

\begin{tabular}{|c|c|c|c|c|}
\hline Variables & $\begin{array}{c}\text { Statistic value of } \\
\text { the series in levels }\end{array}$ & $\begin{array}{c}\text { Rejection } \mathrm{H} 0 \\
\text { up to } 95 \%\end{array}$ & $\begin{array}{c}\text { Statistic value of the } \\
\text { series in first differences }\end{array}$ & $\begin{array}{c}\text { Rejection } \\
\text { H0 up to 95\% }\end{array}$ \\
\hline \multicolumn{7}{|c|}{ Augmented Dickey-Fuller test - H0 has a unit root } \\
\hline GDP & 0.6719 & No & 0.0000 & Yes \\
\hline EMP & 0.2859 & No & 0.0000 & Yes \\
\hline GFCF & 0.3535 & No & 0.0000 & Yes \\
\hline GDP & 0.6906 & No & 0.0000 & Yes \\
\hline EMP & 0.2851 & No & 0.0000 & Yes \\
\hline GFCF & 0.3480 & No & 0.0000 & has a unit root \\
\hline
\end{tabular}

Source: Own data processing in Eviews 
Identifying a long-run equilibrium relationship between the model variables will be achieved using the Johansen cointegration test using the Trace and Max-Eigenvalue tests. Thus, the non-stationary variables (used at level) in Table 1 will allow accurate determination of the econometric model. The Johansen cointegration test was applied after selecting the optimal number of lags. According to the criteria presented in Table 2: Sequential modified LR test statistic, Final prediction error and Akaike information criterion, a number of four lags will be chosen which will make it possible to apply the cointegration test.

Table 2. Criterion for selecting the appropriate number of lags required to apply the Johansen co-integration test

\begin{tabular}{|c|c|c|c|c|c|c|}
\hline \multicolumn{7}{|c|}{$\begin{array}{l}\text { VAR Lag Order Selection Criteria } \\
\text { Endogenous variables: GDP EMP GFCF } \\
\text { Exogenous variables: C } \\
\text { Sample: } 2000 Q 12018 Q 2 \\
\text { Included observations: } 68\end{array}$} \\
\hline Lag & LogL & LR & FPE & AIC & SC & $\mathrm{HQ}$ \\
\hline 0 & 209.9408 & NA & $4.56 e-07$ & -6.086493 & -5.988574 & -6.047694 \\
\hline 1 & 485.6323 & 518.9488 & $1.79 e-10$ & -13.93036 & $-13.53868^{*}$ & -13.77517 \\
\hline 2 & 499.4812 & 24.84655 & $1.55 \mathrm{e}-10$ & -14.07298 & -13.38754 & $-13.80139^{*}$ \\
\hline 3 & 505.6047 & 104.4606 & $1.70 \mathrm{e}-10$ & -13.98837 & -13.00918 & -13.60039 \\
\hline 4 & 518.8208 & $21.37887^{*}$ & $1.51 \mathrm{e}-10^{*}$ & $-14.11238^{*}$ & -12.83942 & -13.60799 \\
\hline 5 & 524.4719 & 8.642911 & $1.69 \mathrm{e}-10$ & -14.01388 & -12.44717 & -13.39310 \\
\hline 6 & 531.8316 & 10.60665 & $1.81 \mathrm{e}-10$ & -13.96564 & -12.10517 & -13.22846 \\
\hline $\begin{array}{l}\text { * indic } \\
\text { LR: } s \\
\text { FPE: } \\
\text { AIC: } \\
\text { SC: } S \\
\text { HQ: }\end{array}$ & $\begin{array}{l}\text { es lag orde } \\
\text { uential mod } \\
\text { tal predictic } \\
\text { aike informe } \\
\text { warz inform } \\
\text { inan-Quinn }\end{array}$ & $\begin{array}{l}\text { ected by the } \\
\text { LR test stati } \\
\text { ror } \\
\text { criterion } \\
\text { n criterion } \\
\text { rmation crite }\end{array}$ & $\begin{array}{l}\text { rion } \\
\text { each test a }\end{array}$ & vel) & & \\
\hline
\end{tabular}

Source: Own data processing in Eviews

The Trace and Max-Eigenvalue tests, defining for the Johansen cointegration test, are presented in Table 3, with intercept (no trend) in the CE and test VAR. They confirm the inexistence of a cointegration relationship, since the $p$-value is greater than the 0.05 significance level, the null hypothesis being accepted. In this regard, the existence of a short-run relationship between the model variables can be considered.

In order to move to the next stage in the econometric analysis, it must be taken into account that both the integration order I(1) of the time series and the lack of cointegration relationships make it possible to fulfill the conditions for running the unrestricted VAR model. Coefficients of the unrestricted vector autoregressive model will provide evidence of a short-run relationship between GDP, EMP and GFCF variables. The variables used have been transformed by applying the first order differences, which will allow for the correct estimation of the model.

The unrestricted VAR model was designed by choosing a number of 3 lags without imposing any restriction on the coefficients. It must be taking into account that too many lags could reduce degrees of freedom. Table 4 shows the optimal number of lags proposed by each selection criterion. According to the Sequential modified LR test statistic, 
the optimal lag number was chosen, as the best stability of the VAR model was observed, as demonstrated by the tests applied and presented below.

Table 3. Johansen cointegration test

\begin{tabular}{|c|c|c|c|c|}
\hline \multicolumn{5}{|c|}{$\begin{array}{l}\text { Sample (adjusted): 2001Q2 2018Q2 } \\
\text { Included observations: } 69 \text { after adjustments } \\
\text { Trend assumption: Linear deterministic trend } \\
\text { Series: GDP EMP GFCF } \\
\text { Lags interval (in first differences): } 1 \text { to } 4 \\
\text { Unrestricted Cointegration Rank Test (Trace) }\end{array}$} \\
\hline $\begin{array}{l}\text { Hypothesized No. of } \\
\qquad \text { CE(s) }\end{array}$ & Eigenvalue & Trace Statistic & 0.05 Critical Value & Prob. ${ }^{* *}$ \\
\hline None & 0.170401 & 22.67846 & 29.79707 & 0.2622 \\
\hline At most 1 & 0.129387 & 9.788403 & 15.49471 & 0.2974 \\
\hline At most 2 & 0.003298 & 0.227925 & 3.841466 & 0.6331 \\
\hline \multicolumn{5}{|c|}{$\begin{array}{l}\text { Trace test indicates no cointegration at the } 0.05 \text { level } \\
\text { * denotes rejection of the hypothesis at the } 0.05 \text { level } \\
\text { **MacKinnon-Haug-Michelis (1999) p-values } \\
\text { Unrestricted Cointegration Rank Test (Maximum Eigenvalue) }\end{array}$} \\
\hline $\begin{array}{l}\text { Hypothesized No. of } \\
\text { CE(s) }\end{array}$ & Eigenvalue & $\begin{array}{c}\text { Max-Eigen } \\
\text { Statistic }\end{array}$ & 0.05 Critical Value & Prob. ${ }^{* *}$ \\
\hline None & 0.170401 & 12.89006 & 21.13162 & 0.4624 \\
\hline At most 1 & 0.129387 & 9.560478 & 14.26460 & 0.2424 \\
\hline At most 2 & 0.003298 & 0.227925 & 3.841466 & 0.6331 \\
\hline \multicolumn{5}{|c|}{$\begin{array}{l}\text { Max-eigenvalue test indicates no cointegration at the } 0.05 \text { level } \\
{ }^{*} \text { denotes rejection of the hypothesis at the } 0.05 \text { level } \\
{ }^{* *} \text { MacKinnon-Haug-Michelis (1999) p-values }\end{array}$} \\
\hline
\end{tabular}

\section{Table 4. VAR lag order selection criteria}

\begin{tabular}{|c|c|c|c|c|c|c|}
\hline \multicolumn{7}{|c|}{$\begin{array}{l}\text { VAR Lag Order Selection Criteria } \\
\text { Endogenous variables: EMP GDP GFCF } \\
\text { Exogenous variables: C } \\
\text { Sample: } 2000 \text { Q1 2018Q2 } \\
\text { Included observations: } 67\end{array}$} \\
\hline Lag & LogL & LR & FPE & $\mathrm{AIC}$ & SC & $\mathrm{HQ}$ \\
\hline 0 & 469.5870 & NA & $1.79 \mathrm{e}-10$ & -13.92797 & $-13.82925^{*}$ & -13.88891 \\
\hline 1 & 483.7569 & 26.64799 & $1.54 \mathrm{e}-10^{*}$ & $-14.08230^{*}$ & -13.68743 & $-13.92605^{\star}$ \\
\hline 2 & 487.8309 & 7.296698 & $1.78 \mathrm{e}-10$ & -13.93525 & -13.24423 & -13.66181 \\
\hline 3 & 499.8160 & $20.39243^{*}$ & $1.64 \mathrm{e}-10$ & -14.02436 & -13.03718 & -13.63373 \\
\hline 4 & 504.5914 & 7.697778 & $1.88 \mathrm{e}-10$ & -13.89825 & -12.61492 & -13.39044 \\
\hline 5 & 506.6223 & 3.091730 & $2.34 \mathrm{e}-10$ & -13.69022 & -12.11074 & -13.06521 \\
\hline 6 & 511.2025 & 6.562655 & $2.72 \mathrm{e}-10$ & -13.55828 & -11.68265 & -12.81609 \\
\hline $\begin{array}{l}\text { * ind } \\
\text { LR: } \\
\text { FPE } \\
\text { AIC: } \\
\text { SC: } \\
\text { HQ: }\end{array}$ & $\begin{array}{l}\text { es lag ordel } \\
\text { uential mod } \\
\text { nal predictio } \\
\text { aike informa } \\
\text { nwarz inform } \\
\text { nnan-Quinn }\end{array}$ & $\begin{array}{l}\text { ected by the } \\
\text { LR test statis } \\
\text { ror } \\
\text { criterion } \\
\text { n criterion } \\
\text { rmation criter }\end{array}$ & $\begin{array}{l}\text { on } \\
\text { ach test at } 5\end{array}$ & vel) & & \\
\hline
\end{tabular}

Source: Own data processing in Eviews 
The Wald test is a safety test for the number of lags chosen from the selection criteria. The P-value common to the model variables indicates the possibility of using the chosen lag if its value is at a significance level of less than 0.05 . The variables used indicate a common $p$-value of 0.0069 , less than the significance level indicated. Thus, the vector autoregressive model will be estimated by using a number of three lags.

\section{Table 5. VAR lag exclusion Wald Test}

\begin{tabular}{|c|c|c|c|c|}
\hline \multicolumn{5}{|c|}{$\begin{array}{l}\text { VAR Lag Exclusion Wald Tests } \\
\text { Sample: 2000Q1 2018Q2 } \\
\text { Included observations: } 70 \\
\text { Chi-squared test statistics for lag exclusion: } \\
\text { Numbers in [ ] are p-values }\end{array}$} \\
\hline & GDP & EMP & GFCF & Joint \\
\hline \multirow[t]{2}{*}{ Lag 1} & 4.459925 & 2.870833 & 2.339309 & 28.32951 \\
\hline & {$[0.2159]$} & {$[0.4120]$} & {$[0.0000]$} & {$[0.0008]$} \\
\hline \multirow[t]{2}{*}{ Lag 2} & 1.446086 & 3.523540 & 1.712692 & 6.947514 \\
\hline & [ 0.6948] & {$[0.3177]$} & {$[0.6341]$} & [ 0.6426] \\
\hline \multirow[t]{2}{*}{ Lag 3} & 6.610606 & 1.560367 & 1.260494 & 22.70890 \\
\hline & {$[0.0854]$} & {$[0.0014]$} & [ 0.7385] & [ 0.0069$]$ \\
\hline df & 3 & 3 & 3 & 9 \\
\hline
\end{tabular}

Source: Own data processing in Eviews

As an extension to determining the optimal number of lags, the stability of the VAR model was also considered. Figure 1 shows the inverse roots of the autoregressive characteristic polynomial. The condition that must be satisfied in order for a model to be dynamically stable is that the roots of the autoregressive model equation to be found within the circle. The characteristic equation has three real roots and two complex pairs of conjugated roots, the inverse roots are distributed only within the unit circle. The AR process is stationary, since all the roots of the equation are within the unit circle.

The stability of the VAR model has also been demonstrated by applying a series of diagnostic tests to meet the requirements for the quality of residuals. According to Table 6 , no heteroskedasticity or autocorrelation of residuals was found in the analyzed model. Autocorrelation LM Test rejects the null hypothesis that there is no serial correlation at a lag $\boldsymbol{h}$ at a significance level of less than 0.05 . The White Heteroskedasticity Test (No Cross Terms) uses elements similar to those of the Autocorrelation LM Test in determining the absence of heteroskedasticity, rejecting the null hypothesis also at a significance level of less than 0.05 . Normality Test - Cholesky (Lutkepohl) was not applied to check the normal distribution of the residuals. „According to the central limit theorem, (a) if the sample data are approximately normal then the sampling distribution too will be normal; (b) in large samples (> 30 or 40 ), the sampling distribution tends to be normal, regardless of the shape of the data; and (c) means of random samples from any distribution will themselves have normal distribution" (Ghasemi et al. 2005). Taking into account the hypotheses of the theorem, the specific residuals of the analyzed model fulfill the normal distribution condition, since each sample consists of a number of 74 observations. 


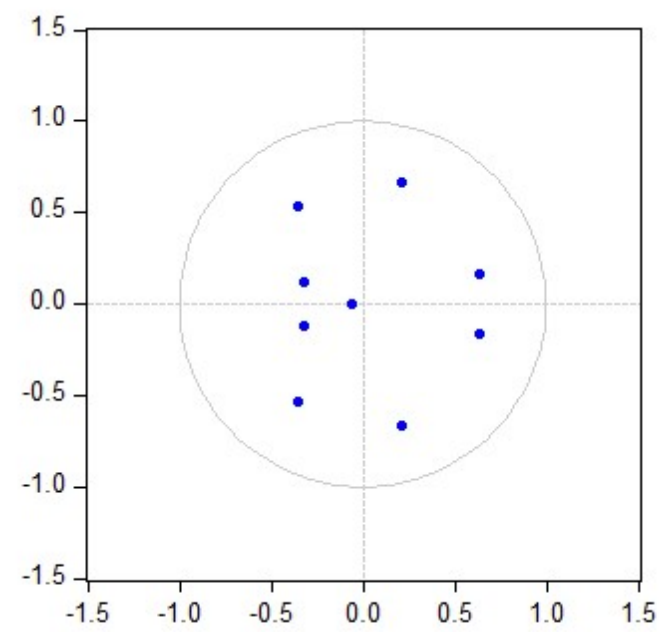

Fig. 1. Inverse Roots of AR Characteristic Polynomial Source: Own data processing in Eviews

Table 6. Diagnostic tests applied to VAR residuals

\begin{tabular}{|c|c|}
\hline Autocorrelation LM Test & $\begin{array}{c}\text { White Heteroskedasticity Test (No } \\
\text { Cross Terms) }\end{array}$ \\
\hline Null hypothesis: No serial correlation at lag h & Null hypothesis: No heteroskedasticity \\
\hline $\mathbf{0 . 3 8 3 0}$ & 0.0955 \\
\hline
\end{tabular}

Source: Own data processing in Eviews

According to the steps followed, it can be stated that the stability of the VAR model was demonstrated. The Johansen cointegration test, as well as the integration order I (1) of the variables, required the autoregressive vector to run. Also, by analyzing the inverse roots of the autoregressive characteristic polynomial, it was found that they were distributed in the center of the unit circle, demonstrating the validity of the VAR model. The general picture of the correct estimation of the autoregressive vector was outlined by the analysis of model residuals related to the absence of autocorrelation, heteroskedasticity, as well as their normal distribution.

Below, we will estimate the multivariate Granger causality that allows predictability in the sense that a variable $\boldsymbol{y}$ Granger - causes a variable $\boldsymbol{x}$. After estimating the causality, the impulse - response function will also be estimated to identify the changes occurring on the dependent variable in the case of a shock produced by the independent variable. In this way, it will be possible to specify how the three variables, more exactly, gross domestic product, employment and investments are interconnected and how they define the evolution of the economic growth in Romania. 


\section{Empirical results}

The Granger causality test and the impulse - response function can still be applied as the stability of the VAR model has been demonstrated. These estimates will help to analyze the economic situation of Romania, having two main objectives. The first objective focuses on the Granger causality test and refers to determining the cause - effect relationship between the variables through a comparison with the economic reality of Romania. The second objective reaches out for estimation of the impulse - response function and refers to the analysis of the changes produced at the level of the dependent variable in case of a positive shock of $1 \%$ on it. This estimate provides the indices about the variables that best respond to a shock produced by an independent variable, as well as their prediction for a specified period of time. The response of interest variables to the economic impulses can only be explained if their value is greater than one.

\subsection{Multivariate Granger causality}

It is imperative to know the causes underpinning the evolution of the national economy, the determinants and the generated effects. The business environment plays a defining role in supporting the development of a sustainable economy of a country, as it is the indispensable tool for financing society. A thriving economy can lead to more employment and can influence national investments. Applying the Granger causality test will become an absolute necessity. It will provide an overview of the causality produced between the three variables analyzed in Romania.

Thus, in Table 7 the causality of the three variables was investigated based on the Granger Causality / Block Exogenity Wald Test. The existence of a causal relationship between the variables of a model under analysis is verified only if the p-value is at a significance level of less than 0.05 . In the first causal relationship, the p-value of the GFCF variable is greater than the level of 0.05 , however, it will be retained in the model at a significance level of $10 \%$. This demonstrates that GFCF causes GDP. The situation is different for the EMP variable, as the $p$-value is 0.7254 , which indicates that EMP does not cause GDP. In the case of the second relationship, the situation is different. The CFGF variable causes the EMP variable at a value of 0.0020 . Moreover, the common $p$-value for GDP and GFCF variables is 0.0177 , demonstrating that they together cause EMP. The third relationship is similar to the second because the null hypothesis is rejected, so GDP and EMP cause GFCF together. Individually, GDP causes GFCF at a value of 0.0007 , but EMP does not cause GFCF.

These cause - effect relationships can be translated into the assertion that GDP precedes GFCF and EMP. The GDP and GFCF variables have determined a feedback system. "Often you will have that $x_{t}$ Granger causes $x_{t}$ and $x_{t}$ Granger causes $x_{t}$. In this case we talk about a feedback system. Most economists will interpret a feedback system as simply showing that the variables are related (or rather they do not interpret the feedback system)" (Sørensen, 2005). The interpretation of this feedback system is of particular importance because it can be concluded that at the level of the Romanian economy the variables GDP and GFCF are associated. In other words, an increase in 
gross domestic product may have as its main cause the increase in investments, but also an increase in investments may have as its main cause an increase in gross domestic product. It can thus see an interconnection between variables that determine a feedback system. According to the results of this test, a unidirectional causal relationship from GDP to GFCF and EMP was shown, as well as a bidirectional relationship in which GDP determines GFCF and vice versa. The causal relationships were transposed into Figure 2 in order to highlight the cause - effect relationship between the variables of interest. The only variable that causes GDP in relation I is the GFCF. Thus, the causal relationship presented above is valid.

Table 7. Granger Causality

\begin{tabular}{|c|c|c|c|}
\hline \multicolumn{4}{|c|}{$\begin{array}{l}\text { VAR Granger Causality/Block Exogeneity Wald Tests } \\
\text { Sample: } 2000 \mathrm{Q} 12018 \mathrm{Q} 2 \\
\text { Included observations: } 70 \\
\text { Dependent variable: GDP }\end{array}$} \\
\hline Excluded & Chi-sq & $\mathrm{df}$ & Prob. \\
\hline EMP & 1.315717 & 3 & 0.7254 \\
\hline GFCF & 7.629667 & 3 & 0.0543 \\
\hline All & 8.206461 & 6 & 0.2234 \\
\hline \multicolumn{4}{|c|}{ Dependent variable: EMP } \\
\hline Excluded & Chi-sq & df & Prob. \\
\hline GDP & 2.198538 & 3 & 0.5322 \\
\hline GFCF & 14.76229 & 3 & 0.0020 \\
\hline All & 15.35423 & 6 & 0.0177 \\
\hline \multicolumn{4}{|c|}{ Dependent variable: GFCF } \\
\hline Excluded & Chi-sq & df & Prob. \\
\hline GDP & 17.14808 & 3 & 0.0007 \\
\hline EMP & 6.529062 & 3 & 0.0885 \\
\hline All & 22.57897 & 6 & 0.0010 \\
\hline
\end{tabular}

Source: Own data processing in Eviews

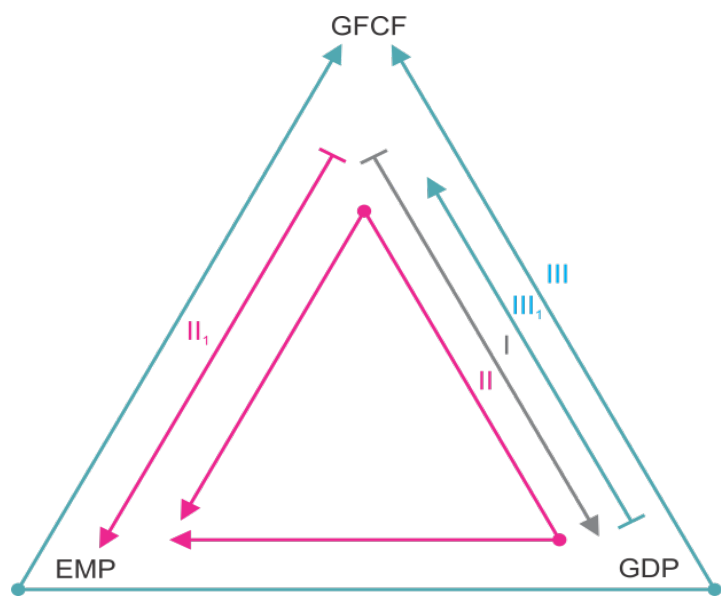

Fig, 2. Causality

Source: Own data processing 
The Granger Causality Test helped to analyze the GDP, GFCF and EMP variables to determine the current economic situation in Romania. An increase in gross domestic product was observed from 2000 to the last quarter of 2008, when the economic crisis triggered in the United States occurred. In the post-crisis years, in 2008-2009, the Romanian economy experienced a stage of instability in which gross domestic product decreased abruptly. In the same context, the investments had a similar pattern. A relaunch of the economy was felt only in the years 2013-2014, when both gross domestic product and investments again picked up positive values compared to previous years. All these aspects of the economic recovery have resulted in a decrease in the unemployment rate and an increase in the employment. Foreign investments also had a contribution, as they were characterized by the contribution of know-how and implicitly the use of human resources. However, the causal relationship generated by the Granger test has its origin engaged in the economic reality of Romania. The GDP and GFCF variables are interconnected, causing EMP in turn.

\subsection{The impulse - response function}

Alloza (2017) specifies that the impulse - response functions represent the evolution of the interest variables within a specified time horizon after a shock is produced at a given time. In the combined Graph 1 of the impulse - response function, the gross domestic product response to the investments and employment shock is surprised. Gross domestic product responds negatively to the change with one standard deviation of employment in the fourth and fifth quarters when it reaches the lowest negative value of $0,15 \%$. Gross domestic product will respond positively to the employment shock by a change of $0,03 \%$ in the sixth quarter and will return negative values during the seventh period by a change of $0,01 \%$. The effect will disappear by the end of the analyzed period. Regarding the response of gross domestic product to the investments shock, it will respond positively until the sixth period. A change of $0,41 \%$ is easily visible, but insignificant, in the fourth period, while it will easily receive a negative value of $0,01 \%$ in the seventh period. The effect will gradually disappear from the eighth period.

Analyzing the response of employment to the investments and gross domestic product shock, it was identified according to the combined Graph 2 of the impulseresponse function that it will respond negatively but insignificantly to the investments shock only in the second, third and sixth period. A positive value of $0,48 \%$ will be recorded only in the fourth period, following that the effect to be very weak until the end of the period, almost non-existent. Employment will respond similarly to the gross domestic product shock. This will have negative values in the third and fourth period, changing by $0,04 \%$ and $0,05 \%$, and in the following periods the effect will gradually disappear.

The response of investments to the employment shock is negative, with the exception of certain periods in which it will have positive but close to zero values shown in Graph 3. In the case of the response of investments to the gross domestic product shock, there is a positive change of $2,99 \%$ in the second period. After this time, the effect will disappear to the end. The employment shock is different from the gross domestic product shock as the percentage of the changes will be negative for most periods, the only positive 
value being identified in the third period when the investments will have a change of $0,6 \%$. The effect will disappear from the sixth period by the end of the analyzed period.

Response of EMP to Innovations

using Cholesky (d.f. adjusted) Factors

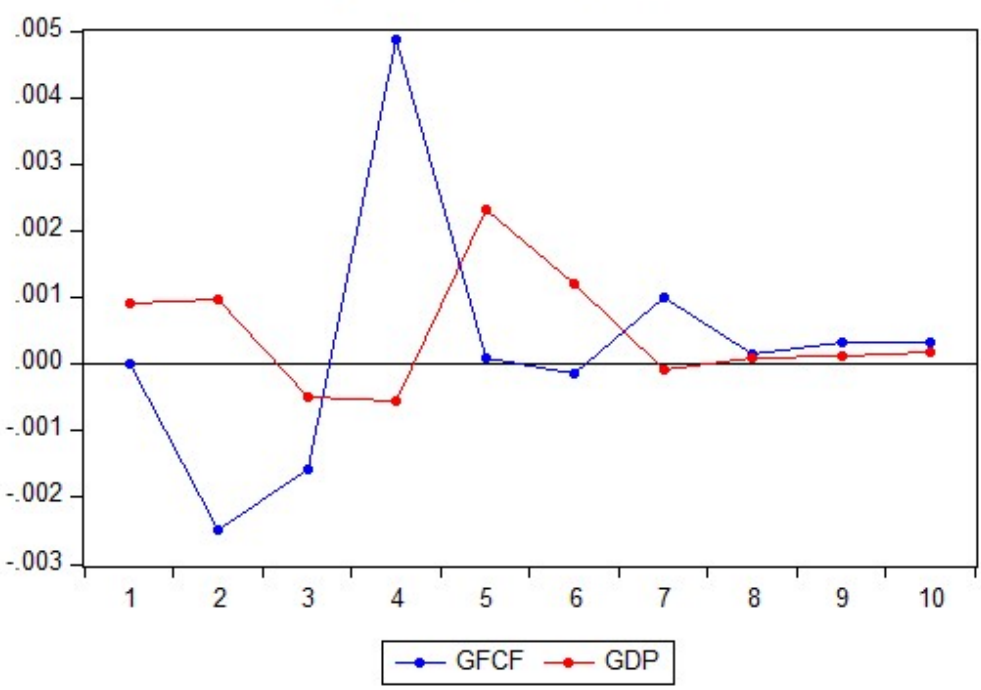

Graph 1. The impulse - response function of GDP

Source: Own data processing in Eviews

Response of GDP to Innovations using Cholesky (d.f. adjusted) Factors

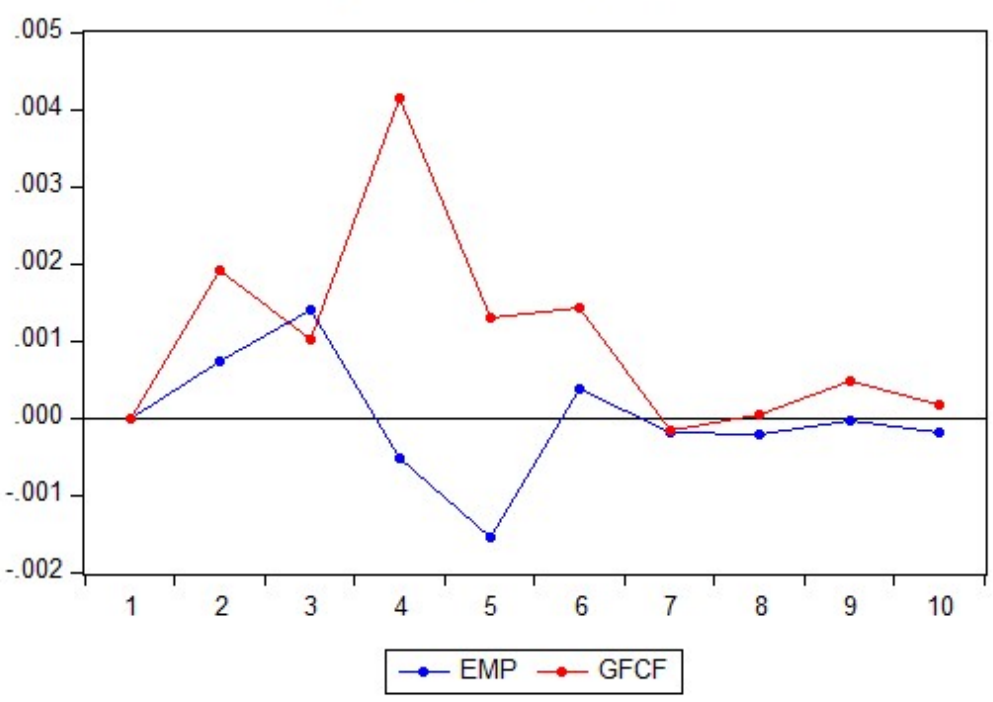

Graph 2. The impulse - response function of EMP

Source: Own data processing in Eviews 


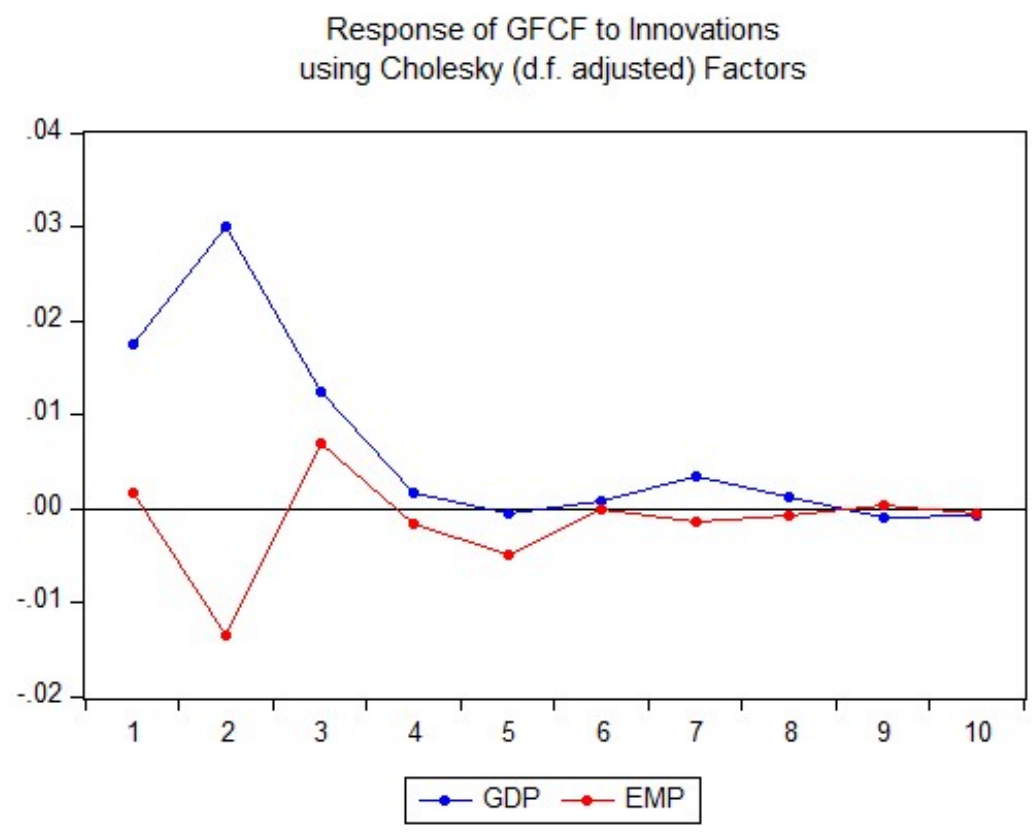

Graph 3. The impulse - response function of GFCF

Source: Own data processing in Eviews

Following the estimation of the impulse-response function, a positive relationship between gross domestic product and investments was identified. It should be considered that the response of gross domestic product to the investments shock and vice versa had low values, close to zero. This may be due to investments made in country by the foreign investors and which do not necessarily produce effects on gross domestic product. In Romania it was observed that the absorption of the reimbursable and non-reimbursable funds allocated by the European Union generated an increase in investments. Instead, a negative relationship between investments and employment was identified, which may be due to the fact that the need for human resources is no longer a priority in some sectors of activity due to technology. However, the relationship between gross domestic product and employment remains uncertain, as the response of gross domestic product to the employment shock and vice versa had both negative and positive values for the first period.

\section{Conclusions}

Economic growth in Romania did not have an imperturbable growth, due to both fiscal policies and applied legal norms, as well as to exogenous factors, such as the global financial crisis, which has destabilized the entire business environment. This fluctuating and unviable growth made it difficult for the whole process of socio-economic development even if the financial prospects of the European Union had plans to combat the recession and to balance the economy. Whereas real economic growth also involves attracting 
investments, they can not also guarantee an increase in employment. Based on the econometric processing of data existing in Romania between the first quarter of 2000 and the second quarter of 2018, the vector autoregressive model (VAR) was used to analyze the effects of investments on growth and employment.

Using the Granger Causality/Block Exogenity Wald Test was investigated the causality between the three variables. The results revealed a causal relationship between the variables of the model under analysis as GDP and GFCF are interconnected, causing EMP in turn. This result is engaging in the economic reality of Romania, because both during the relaunch of the economy and during the post-crisis period, the investments and the gross domestic product manifested themselves in the sense of mutual dependence. An increase in gross domestic product was to generate an increase in investments and vice versa, and employment being directly influenced by these variations, as evidenced by the common p-value for GDP and GFCF, which is 0.0177 , that proves that they cause EMP together. Moreover, in order to represent the evolution of the variables of interest within a specified time horizon, the impulse -response functions were used. Following the analysis of GFCF response to GDP and EMF, a positive relationship between gross domestic product and investments has been identified and the relationship between investment and the employment remains negative due to the fact that the need for human resources is no longer a priority in some sectors of activity due to technology.

The conclusion based on the analysis of the vector autoregressive model (VAR) emphasizes the fluctuating aspects of the evolution of the Romanian economy. Thus, the interdependence between investments and gross domestic product means a development of the economy, influenced especially by the capacity of the business environment. At the same time, an increase in investments can not lead to an increase in employment, so that, due to the technology that will offer the possibility of reducing the production costs, as well as the working time, a discrepancy will be distinguished growing between them.

\section{References}

Alloza, M., (2017), A Very Short Note on Computing Impulse Response Functions, University College, London, available online at http://www.ucl.ac.uk/ uctp041/Teaching files /Tutorial IRF.pdf.

Attanasio, O.P., Picci, L., Scorcu, A.E., (2000), Saving, growth, and investment: a macroeconomic analysis using a panel of countries, Review of Economics and Statistics, Vol. 82, no. 2, pp. 182-211.

Blomstrom, M., Lipsey, R.E., Zejan, M., (1993), Is fixed investment the key to economic growth?, NBER Working Papers 4436, National Bureau of Economic Research, Inc.

Bond, S., Leblebicioğlu, A., Schiantarelli, F., (2010), Capital accumulation and growth: a new look at the empirical evidence, Journal of Applied Econometrics, Vol. 25, no. 7, pp. 1073-1099.

Cheung, Y.W., Dooley, M.P., Sushko, V., (2012), Investment and growth in rich and poor countries, NBER Working Papers 17788, National Bureau of Economic Research, Inc.

Ghasemi, A., Zahediasl, S., (2012), Normality tests for statistical analysis: a guide for nonstatisticians, International journal of endocrinology and metabolism, Vol. 10, no. 2, pp. 486489. 
Jayaraman T. K., and Singh B., (2007), Foreign Direct Investment and Employment Creation in Pacific Island Countries: An Empirical Study of Fiji, Asia-Pacific Research and Training Network on Trade Working Paper Series, no. 35.

Jula, D. and Jula, N.M., (2017), Foreign Direct Investments and Employment. Structural Analysis, Romanian Journal of Economic Forecasting, Vol. 20, no. 2, pp. 29-44.

Maitah, M., Hayat, A., Malec, K. and Eldeeb, O., (2014), The impact of foreign direct investments on employment in the Czech Republic, Research Journal of Applied Sciences, Vol. 9, no. 12, pp. 1001-1008.

Mordecki, G., Ramírez, L., (2014), Investment, growth and employment: VECM for Uruguay, Serie Documentos de Trabajo, FCEA-IE, DT07/14, available online at https://hdl.handle.net/20.500.12008/4256.

Mucuk, M. and Demirsel, M.T., (2013), The effect of foreign direct investments on unemployment: evidence from panel data for seven developing countries, Journal of Business, Economics, Vol. 2, pp. 3.

Sørensen, B. E., (2005), Granger causality, Economics, 7395, available online at https://ssl.uh.edu/ bsorense/gra caus.pdf.

Yaylı, S. and Değer, M. K., (2012), The Relationships Between Foreign Direct Investments and Employment: Dynamic Panel Data Causality Analysis on Developing Countries (19912008), Finans, Politik ve Ekonomik Yorumlar, Vol. 49 no. 568, pp. 43-51. 